\title{
West Nile Virus Serosurveillance in Wild Boars from the East of Romania
}

\author{
Anca PÂSLARU*, Daniela POREA, Gheorghe SAVUȚA, Luanda OŞLOBANU (LUDU)* \\ ${ }^{1}$ Department of Public Health, Faculty of Veterinary Medicine, UȘAMV Iași, Aleea Mihail Sadoveanu nr.7, \\ Iaşi, 700490, România \\ *Corresponding author: oslobanule@uaiasi.ro and paslaru.anca@yahoo.com
}

Bulletin UASVM Veterinary Medicine 73(1) / 2016,

Print ISSN 1843-5270; Electronic ISSN 1843-5378

DOI:10.15835/buasvmcn-vm: 11934

\begin{abstract}
West Nile Virus (WNV) is the etiological agent of the WN fever/encephalitis, a re-emerging zoonosis signalled frequently in the last decades in the whole world. The virus can cause severe neurological disease in horses and humans but in many other species specific WNV seroconversion is signalled and may be an useful epidemiological tool. Wild animals can be vectors for many pathogens but the surveillance is limited due to the particularities of those populations. A preliminary serosurvey study was made to evaluate the circulation of WNV in wild boar population from two counties in the south east of Romania. Antibodies against WNV were detected by a competitive ELISA in $43(63.24 \%$ ) of the 68 tested samples (Buzău County 53.33\% and Galaţi County 71.05\%).This is the first attempt to assess the seroconversion of WNV in wild boars in Romania and we can assume that the infection is maintained in tested areas in a sylvatic enzootic transmission circle. Our previous studies had revealed the high seroprevalence of WNV in horses and domestic birds from the studied areas. Moreover, WN encephalitis was diagnosed in humans from Galaţi and Buzău counties. Our results might bring in light the hypothesis of WNV seroconversion in wild boars and point to further studies. Taking in account that WNV is a Flavivirus of the Japanese encephalitis virus antigenic complex, there is a great possibility to cross react with other related viruses infecting the wildboar, so more specific tests are needed in order to confirm our preliminary results.
\end{abstract}

Keywords: anti WNV IgG, competition ELISA, serosurvey, West Nile Virus, wild boar

\section{INTRODUCTION}

West Nile Virus (WNV), a Flavivirus, of the Japanese encephalitis virus (JEV) antigenic complex is the etiological agent of the WN fever/ encephalitis, a re-emerging zoonosis epidemic in certain areas of Europe and frequently signaled in Romania since 1996 . The virus can cause severe neurological disease in horses and humans (some time with fatalities) and mortality in birdsmostly in USA (Komar, 2003). West Nile virus is maintained in nature in a sylvatic enzootic transmission cycle between birds and mosquitoes of Culex spp. (McVey et al., 2015) but there were epidemics in which the transmission cycle was urban as the above mentioned 1996 epidemics from Romania (Ceianu et al., 2001).
As for different lineages diversity of WNV, based on phylogenetic analyses up to nine have been proposed (Pachler et al., 2014). Lineages 1 and 2 are the most important, being responsible for outbreaks in humans and equines (Donadieu et al., 2013). In Europe, until 2004, when the lineage 2 strain was isolated for the first time in Hungary, only lineage 1 strains were circulating. Since then, lineage 2 strains have been isolated in humans and animals in several countries (Kutasi et al., 2011; Hernández-Triana et al., 2014, Barzon et al., 2015, Dinu et al., 2015), being already responsible for dozens of human deaths.

In animals, the presence of anti-WNV antibodies has been demonstrated in several bird species, but few data are available from mammals 
other than horses, as serological evidence of WNV infection has been reported only in a few domestic and wild mammal species (Jeffrey Root, 2013). West Nile Virus seroconversion studies proved that there are many species susceptible to the infection both domestic and wild. The presence of antibodies in other species then in birds which are amplifying hosts can be a proof of virus activity in certain areas. However, data about virus circulation in other susceptible mammals, excepting horses, is scarce.

Free-living mammals are naturally exposed to flaviviral infections and, thus, they may be involved in the virus transmission cycle (EscribanoRomero et al., 2015). The surveillance and control of different diseases in wild animals are limited due to the epidemiological particularities of those populations. Studies can bring new data regarding the emergence and re-emergence mechanisms of diseases with different aetiology and also about hosts and reservoirs for a great variety of pathogens with harmfully potential for domestic animals and also for public health.

Taking in account that, to our knowledge, in our country, in wild mammals, no studies were previously made, our aim was to assess the seroprevalence of the specific anti WNV IgG antibodies in wild boars. A preliminary serosurvey study was carried to evaluate the circulation of WNV in wild boar population in samples collected at the beginning of 2015 from two counties in the south east of Romania (Galaţi and Buzău).

\section{MATERIALS AND METHODS}

The assessment of WNV circulation among wild boars in southeastern Romania was made on 68 samples obtained from 33 hunting grounds, 15 located in Buzău and 18 in Galați counties. At least one wild boar was sampled from each hunting ground.

Buzău County $\left(45^{\circ} 9^{\prime} \mathrm{N} 26^{\circ} 49^{\prime} \mathrm{E}\right)$ is located in the south-east of Romania. In the North Side there are the mountains from the southern end of the Eastern Carpathians group - the Vrancea Mountains and the Buzău Mountains with heights over 1,700 m. The heights decrease in the South and East passing through the subcarpathian hills to the Bărăgan Plain at about $80 \mathrm{~m}$. The main river crossing the county is the Buzău River which collects many small rivers which passes through the hill area and from the mountains and flows to the East into the Siret River. The geographical distribution of the sampled hunting grounds was predominantly in the subcarpathian hills areas (Fig.1).

Galaţi County $\left(45^{\circ} 25^{\prime} 24^{\prime \prime} \mathrm{N} \quad 28^{\circ} 2^{\prime} 33^{\prime \prime} \mathrm{E}\right)$ is located in the Eastern Romania and lays on a low plain, between the Prut River in the East, the Siret River in the West and South. Both rivers flow into the Danube River, which is the border in the
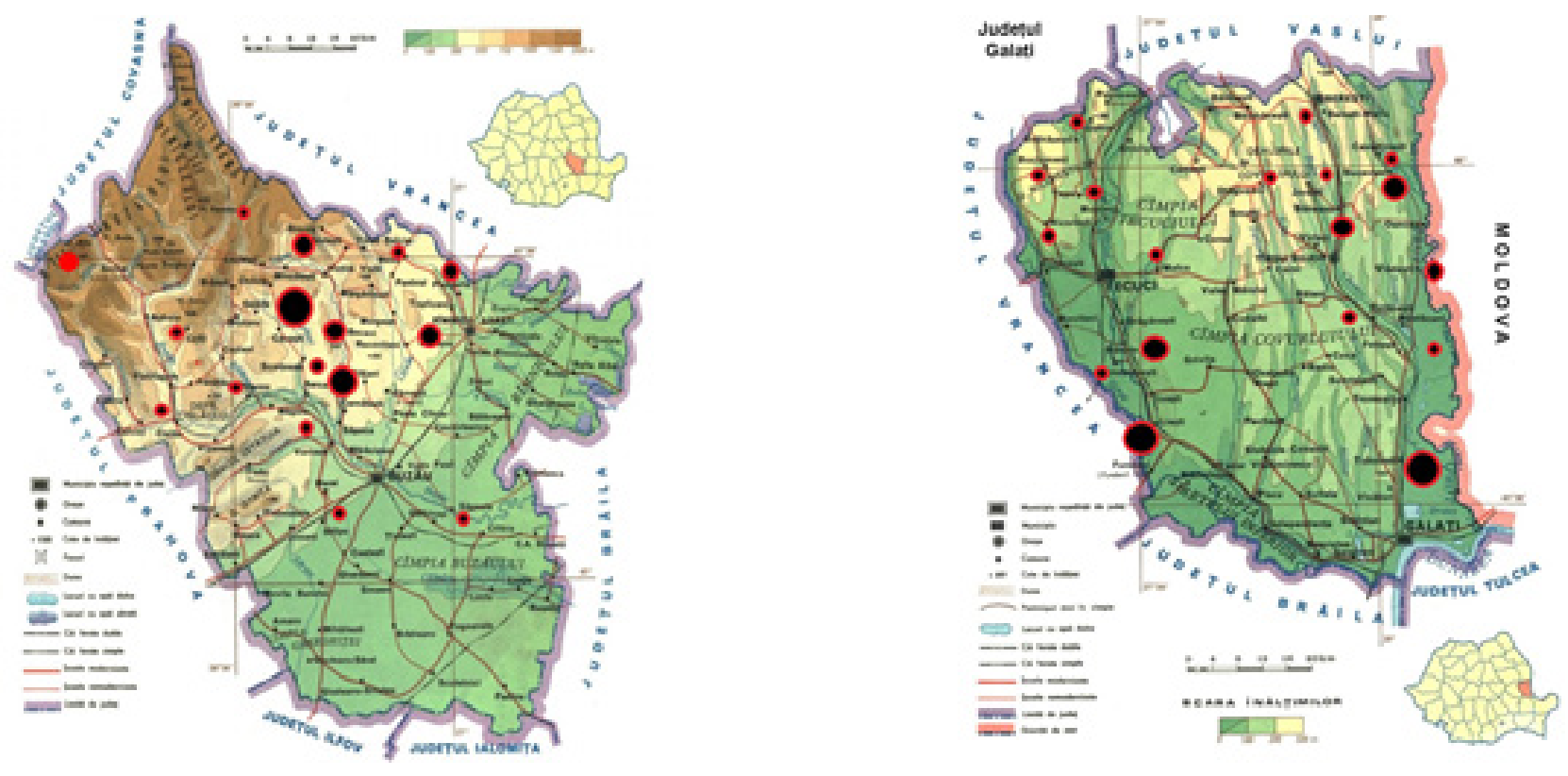

Fig.1. Buzău (left) and Galaţi (right) counties with emphasis on the areas of sample collection 
South-East. Half of the sampled hunting grounds where placed on the hill area and the other half on the plain area of the county. The samples were randomly chosen given the specific of the tested species and distributed as shown in fig.1.

Blood samples from wild boars $(n=68)$ were obtained from hunting drives and trapping programs for the official active sanitary surveillance procedures for classical and african swine fever (NSVFSA 2015). Blood was collected from the thoracic cavity of freshly dead animals. Upon arrival at the laboratory, blood samples were centrifuged for at least $10 \mathrm{~min}$ at $2000 \times \mathrm{g}$ for serum separation and the serum was stored at $-20^{\circ} \mathrm{C}$ until testing.

The presence of antibodies to $\mathrm{WNV}$, was analyzed by a commercial competitive ELISA kit for the detection of anti-pr-E antibodies in multiple species based on purified whole WNV antigen, which is detecting antibodies directed against the PrM-E envelope protein common to flaviviruses (ID Screen ${ }^{\circledR}$ West Nile Competition Multi-species, ID Vet, Montpellier, France). The test was performed according to manufacturer's instructions.

\section{RESULTS AND DISCUSSION}

Using the competitive ELISA we have detected antibodies in 43 (63.24\%) CI (95\%) [52.28-74.18] of the 68 sample tested.

In Buzău County, 16 samples (53.33\%), CI (95\%) [34.75 - 71.91] from 30 tested were positive. The positive samples corresponded to 10 hunting grounds from 15 tested (Tab. 1).

In Galaţi County, the positive samples were distributed in 15 hunting grounds from the 18 tested. Anti-WNV antibodies where detected in 27 samples (71.05\%) CI (95\%) [14.05 - 43.85] (Tab. 2).

Flaviviruses exposure of free-living mammals with a broad geographic range and high population density, such as wild boar, red foxes and other species could be a useful indicator of viral circulation and expand the knowledge on virus ecology in Romanian ecosystems as other studies underlined before (Acevedo et al., 2007; Platt et al., 2008).

This is the first attempt to assess WNV seroconversion in wild boars and due to the high percent of seroprevalence found, we can assume that the infection is maintained in those areas in a sylvatic enzootic transmission circle. Previous studies had revealed the high seroprevalence of WNV in horses and domestic birds from the studied areas and moreover WNV neurological infection where diagnosed in humans from Galaţi in 2014 and Buzău in 2015 (ECDC, 2015). Our results can sustain the hypothesis of the WNV infection in wild boars, in two counties from the East of Romania and point to further studies which are needed to confirm this hypothesis. Taking in account that WNV is a Flaviviruses of the Japanese encephalitis virus (JEV) antigenic complex there is a great possibility to cross react with other related viruses which infect wild boars.

\section{CONCLUSION}

Our preliminary results prove the circulation of West Nile virus and/or related flaviviruses in wild boars in two counties from the East of Romania and point to further studies which are needed to confirm it. Previous seroprevalence studies made in Romania had revealed the high seroprevalence of WNV in horses and domestic birds from the studied areas and moreover WNV neurological infection was diagnosed in humans from Galaţi County. To our knowledge this is the first attempt to assess specific WNV seroconversion in wild

Tab. 1. Positive anti WNV antibodies in samples collected in hunting groundsBuzău County

\begin{tabular}{|c|c|c|}
\hline No. Hunting ground & Tested samples & Positive \\
\hline Aldeni & 1 & 0 \\
\hline Beceni & 3 & 3 \\
\hline Berca & 4 & 2 \\
\hline Breazău & 1 & 1 \\
\hline Cislău & 1 & 1 \\
\hline Coltti & 1 & 0 \\
\hline Dedulești & 1 & 0 \\
\hline Făgetu & 2 & 1 \\
\hline Grăjdana & 1 & 1 \\
\hline Oreavu & 3 & 3 \\
\hline Rușăvăț & 1 & 0 \\
\hline Săgeata & 1 & 1 \\
\hline Stâlpu & 1 & 0 \\
\hline Umbrărelu & 6 & 2 \\
\hline Vintilă Vodă & 3 & 1 \\
\hline TOTAL & 30 & 16 \\
\hline
\end{tabular}


Tab. 2 WNV seroconversion in wild boars in different administrative areas from Galaţi County

\begin{tabular}{|c|c|c|c|c|c|}
\hline Administrative areas & Hunting ground & Total & sted & Positive & Seroconversion (\%) \\
\hline \multirow{8}{*}{ Galaţi } & Buciumeni & 1 & \multirow{8}{*}{14} & 1 & \multirow{8}{*}{36.84} \\
\hline & Nicorești & 1 & & 1 & \\
\hline & Matca & 1 & & 0 & \\
\hline & Mogoș & 1 & & 1 & \\
\hline & Tulucești & 6 & & 5 & \\
\hline & Umbrărești & 1 & & 1 & \\
\hline & Vlădești & 2 & & 2 & \\
\hline & Vlăscuța & 1 & & 1 & \\
\hline \multirow{2}{*}{ Liesti } & Barcea & 4 & \multirow{2}{*}{10} & 2 & \multirow{2}{*}{26.32} \\
\hline & Liești & 6 & & 0 & \\
\hline \multirow{2}{*}{ Tecuci } & Gohor & 1 & \multirow{2}{*}{2} & 1 & \multirow{2}{*}{5.26} \\
\hline & Țepu & 1 & & 1 & \\
\hline \multirow{6}{*}{ Târgu Bujor } & Băneasa & 3 & \multirow{6}{*}{12} & 3 & \multirow{6}{*}{31.58} \\
\hline & Berești & 1 & & 1 & \\
\hline & Cavadinești & 1 & & 0 & \\
\hline & Jorăști & 1 & & 1 & \\
\hline & Suceveni & 5 & & 5 & \\
\hline & Zărnești & 1 & & 1 & \\
\hline \multicolumn{2}{|c|}{ TOTAL } & \multicolumn{2}{|c|}{38} & 27 & 71.05 \\
\hline
\end{tabular}

boars in Romania and due to the high percent of positive samples found, we can assume that the infection is maintained in those areas in a sylvatic enzootic transmission circle between birds and specific vectors.

Acknowledgments. This work was supported by the Swiss National Science Foundation and the Swiss Agency for Development and Cooperation in the framework of the programme SCOPES Scientific co-operation between Eastern Europe and Switzerland.

\section{REFERENCES}

1. Acevedo P, Vicente J, Höfle U, Cassinello J, Ruiz-Fons F, Gortazar C (2007). Estimation of European wild boar relative abundance and aggregation: a novel method in epidemiological risk assessment. Epidemiol Infect 135(3):519-27.

2. Barzon L, Papa A, Lavezzo E, Franchin E, Pacenti M, Sinigaglia A, Masi G,Trevisan M, Squarzon L, Toppo S, Papadopoulou E, Nowotny N, Ulbert S, Piralla A, Rovida F, Baldanti F, Percivalle E, Palù G. (2015). Phylogenetic characterization of Central/Southern European lineage 2 West Nile virus: analysis of human outbreaks in Italy and Greece, 2013-2014. Clin Microbiol Infect.
3. Ceianu CS, Ungureanu A, Nicolescu G, Cernescu C, Nitescu L, Tardei G., (2001).West nile virus surveillance in Romania: 1997-2000. Viral Immunol 14(3):251-62.

4. Dinu S, Cotar AI, Pănculescu-Gătej IR, Fălcuţă E, Prioteasa FL, Sîrbu A, Oprișan G, Bădescu D, Reiter P, Ceianu CS (2015). West Nile virus circulation in South-Eastern Romania, 2011 to 2013. Euro Surveill 20:20.

5. Donadieu E, Bahuon C, Lowenski S, Zientara S, Coulpier M, Lecollinet S (2013). Differential virulence and pathogenesis of West Nile viruses. Viruses. 5(11):285680.

6. ECDC (2015). Reported cases of West Nile fever, transmission season 2015 and previous transmission seasons : updated 20.11.2015, http://ecdc.europa.eu/ en/healthtopics/west_nile_fever/West-Nile-fever maps/ pages/index.aspx

7. Escribano-Romero E, Lupulović D, Merino-Ramos T, Blázquez AB, Lazić G, Lazić S, Saiz JC, Petrović T.( 2015) West Nile virus serosurveillance in pigs, wild boars, and roe deer in Serbia. Vet Microbiol 176(3-4):365-9.

8. Hernández-Triana LM, Jeffries CL, Mansfield KL, Carnell G, Fooks AR, Johnson N (2014). Emergence of west nile virus lineage 2 in europe: a review on the introduction and spread of a mosquito-borne disease. Front Public Health 2:271.

9. Jeffrey Root J ( 2013).West Nile virus associations in wild mammals: a synthesis. Arch Virol 158(4):735-52. 
10. Komar N (2003). West Nile virus: epidemiology and ecology in North America. Adv Virus Res 61:185-234. Review. PubMed PMID: 14714433.

11. Kutasi O, Bakonyi T, Lecollinet S, Biksi I, Ferenczi E, Bahuon C, Sardi S, Zientara S, Szenci O ( 2011). Equine encephalomyelitis outbreak caused by a genetic lineage 2 West Nile virus in Hungary. J Vet Intern Med 25(3):58691.

12. NSVFSA - National Sanitary Veterinary and Food Safety Authority (2015). http://www.ansvsa.ro/?pag=14

13. 13. McVey DS, Wilson WC, Gay CG (2015). West Nile virus. Rev Sci Tech 34(2):431- 9. Review
14. Pachler K, Lebl K, Berer D, Rudolf I, Hubalek Z, Nowotny $\mathrm{N}($ 2013). Putative new West Nile virus lineage in Uranotaenia unguiculata mosquitoes, Austria. EmergInfect Dis 20(12):2119-22.

15. Platt KB, Tiawsirisup BJ, Tucker BJ, Blitvich LC, Bartholomay LC, Rowley WA (2008). The potential of small mammals to contribute to the ecology and epidemiology of West Nile virus Proceedings, 15th Congress of FAVA FAVA-OIE Joint Symposium on Emerging Diseases, Bangkok, Thailand, 61-62. 